\title{
Some Aspects of the Modelling of Thin-Layer Drying of Sawdust
}

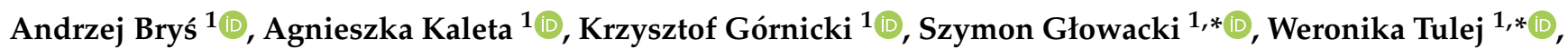 \\ Joanna Bryś $^{2}$ (D) and Piotr Wichowski ${ }^{3}$ (D) \\ 1 Institute of Mechanical Engineering, Warsaw University of Life Sciences, ul. Nowoursynowska 164, \\ 02-787 Warszawa, Poland; andrzej_brys@sggw.edu.pl (A.B.); agnieszka_kaleta@sggw.edu.pl (A.K.); \\ krzysztof_gornicki@sggw.edu.pl (K.G.) \\ 2 Institute of Food Science, Warsaw University of Life Sciences, ul. Nowoursynowska 159c, 02-787 Warszawa, \\ Poland; joanna_brys@sggw.edu.pl \\ 3 Institute of Environmental Engineering, Warsaw University of Life Sciences, ul. Nowoursynowska 159, \\ 02-776 Warszawa, Poland; piotr_wichowski@sggw.edu.pl \\ * Correspondence: glowackisz@gmail.com (S.G.); weronika_tulej@sggw.edu.pl (W.T.)
}

check for

updates

Citation: Bryś, A.; Kaleta, A.; Górnicki, K.; Głowacki, S.; Tulej, W.; Bryś, J.; Wichowski, P. Some Aspects of the Modelling of Thin-Layer Drying of Sawdust. Energies 2021, 14, 726. https://doi.org/10.3390/ en14030726

Received: 18 December 2020

Accepted: 28 January 2021

Published: 30 January 2021

Publisher's Note: MDPI stays neutral with regard to jurisdictional claims in published maps and institutional affiliations.

\begin{abstract}
Drying of spruce, beech, willow, and alder sawdust was examined in a laboratory type dryer. The effect of drying air temperature $T\left(25,60\right.$, and $\left.80^{\circ} \mathrm{C}\right)$ and airflow velocity $v(0.01,0.15$, and $1.5 \mathrm{~m} / \mathrm{s}$ ) was investigated. The obtained results demonstrated that drying air temperature and airflow velocity have impacts on the drying of sawdust. The experimental dehydration data of sawdust obtained were fitted to theoretical, semi-theoretical, and empirical thin-layer models. The accuracies of the models were estimated using the correlation coefficient $(R)$, root mean square error (RMSE), and reduced chi-square $\left(\chi^{2}\right)$. All models except the theoretical model of a sphere described the drying characteristics of sawdust satisfactorily. The effect of $T$ and $v$ on the parameters (constants and coefficients) of the drying models were determined. The effect, by the proposed equations, was also described. This work combines aspects of mechanical engineering and modelling of the drying process.
\end{abstract}

Keywords: sawdust; drying; dehydration; modelling; mechanical engineering

\section{Introduction}

The term biomass is applied to refer to all biologically produced matter [1]. Wood, energy crops, and agricultural and forest residues that belong to the most common resources of renewable energy can be classified as biomass [2,3]. The first type of biomass used by human beings was wood [4]. It has been utilized in the process of direct combustion, which people still rely on all over the world [1]. However, to reduce global carbon dioxide emission, bioenergy has become increasingly important $[5,6]$. Wood based biofuels are cheaper alternatives to fossil fuels due to environmental taxes imposed on carbon dioxide caused by both economic and ecological factors [7-9].

The main issue with woody biomass is its high initial moisture content $[10,11]$. The optimum moisture content of the material must be obtained for the purpose of reaching the optimal densification of the biomass and also to recover energy $[12,13]$. The moisture content of such biomass typically varies between 1 and $1.7 \mathrm{~kg} \mathrm{H}_{2} \mathrm{O} / \mathrm{kg} \mathrm{d.m.} \mathrm{(50-63 \%} \mathrm{w.b.)}$ depending on the season, weather, and type of biofuel [14]. Obviously, combustion of dried wood is easier in comparison with wet. During the combustion of wet wood fuel, approx. $10 \%$ of the energy obtained is used for the vaporization of the water it contains [15]. In addition, the heating value of the wood fuel is negatively correlated with the fuel moisture content $[3,16]$. The moisture content of woody biomass can be reduced by drying. Large amounts of excess moisture contained in the wood to be transported and handled increase delivery costs, energy consumption, and emissions [6]. Dried and compressed biofuels, in the form of briquettes or pellets, have controlled moisture content and a higher energy density. Moreover, it is easier to transport them. They also occupy less space and are less 
susceptible to mold and insects while stored [17]. Today, processed wood fuels (pellets or briquettes) are made from dry sawdust and cutter shavings. Before the pelleting process begins, the raw material should be dried to a moisture content of $0.09-0.14 \mathrm{~kg} \mathrm{H} \mathrm{H}_{2} \mathrm{O} / \mathrm{kg}$ d.m. (8-12\% w.b.) $[7,15,17]$.

Investigations concerning wood drying have frequently been reported in the literature. Sheikholeslami and Watkinson [18] studied the overall drying times of wood residues in a fixed bed. Moreno and Rios [19] carried out an experimental study on sawdust particle drying with the help of fluidized-bed equipment at a laboratory scale. Di Blasi et al. [20] discussed three main phases of wood cylinders drying in a deep bed, including the heating phase. Hanson and Antti [21,22] investigated the effects of drying method and temperature on the hardness and strength of perpendicular and parallelepiped wood. Karlsson et al. [23] presented experimental data of hot air drying of bark in a deep bed. Kobayashi et al. [24] investigated the drying behavior of wood biomass and the effect of moisture content on fine grinding using a vibration mill. Bengtsson [25] carried out an experimental study on low-temperature bed drying of wooden biomass particles. Kowalski and Pawłowski [26] presented results of experimental studies concerning convective drying of wood in variable and-for comparison—stable drying conditions. Lerman and Wennberg [27] studied a fixed bed drying of wood chips and sawdust. Fagernäs at al. [28] reviewed the most promising and commercially available drying processes, emphasizing the use, operational factors, and emissions of dryers. The most common dryers applied for biomass were discussed.

Drying requires a lot of energy. According to statistics, in Canada, the United States, France, and Great Britain, drying uses up 10-15\% of total national industrial energy demand, and in Denmark and France the amount of the energy used amounts to 20-25\% [29]. Therefore drying units need efficient processes [30]. Crucial issues related with drying technology include mathematical modelling of the drying process as well as equipment [31]. It enables the prediction of drying rate and efficiency under a range of conditions. Accurate prediction can contribute to determination of the best quality of end product and reduce the duration of the drying process $[32,33]$.

The models are theoretical, empirical, and semi-empirical, and despite the widespread use of computers and their associated software, empirical equations are still widely used because of their simplicity and ease of computation [34]. Theoretical models, however, are based on the general theory of mass and heat transfer laws. They take into account the fundamentals of the drying process, and their parameters have physical meaning. Therefore, theoretical models can give an explanation of the phenomena occurring during drying. On the other hand, however, these models are more difficult to apply compared to the other mentioned models [35].

There are few papers related to mathematical modelling of wood drying. Reuss et al. [36] described the solar wood drying using the TRNSYS [37] simulation model. The model was designed for the purpose of describing a wood staple drying, but it can be applied to calculate the drying of single boards as well. Fyhr and Rasmuson [38] and Johansson et al. [39] conducted research on high temperature convective drying of single wood chips using air and superheated steam, respectively. The 2D model presented described the coupled transport of water, vapor, air, and heat. Gigler et al. [40] developed a theoretical drying model for willow stem. Radial water transport in a stem was described as a function of time and place with a diffusion equation for a non-shrinking cylinder. Gigler et al. [6,41] described the forced convective drying process of willow chips and natural wind drying process of willow chunks with a PDE (Partial Differential Equation) deep bed drying model. Dincer [42] proposed a moisture transfer analysis technique to determine the moisture diffusivities and moisture transfer coefficients for slab shaped wood subjected to drying and verified it with the experimental data taken from the literature. Weres et al. [43] developed the method to identify mathematical model coefficients of the heat and mass transport in wood and applied the developed method for estimation of temperature-dependent thermal conductivity in the three anatomic directions of beech wood. Awadalla et al. [44] created the TRNSYS simulation model, which allows the methods used to dry solar timber to be 
optimized. A computer subprogram was developed using a transient theoretical analysis and was included in the TRNSYS deck. The model proved to be effective for the prediction of boards drying in a tunnel industrial dryer and solar tunnel dryer.

Artificial neural networks (ANN) were also used for modelling of various processes [45-47]. Determining the appropriate dehydration parameters is very important for optimizing the amount of energy consumed during drying and the quality of the product. Balbay et al. [48] used ANNs (backpropagation learning algorithm with LevenbergMarguardt (LM) and scaled conjugate gradient and sigmoid transfer function) to optimize the drying of Siirt pistachios. Nadi et al. [49] presented an optimization algorithm successfully applied in the drying process, where relations between material quality parameters (five), energy consumption, and drying parameters were approximated using ANN. A feed forward neural network (modelling the nonlinear behavior of drying terebinth fruit) was able to predict the optimal conditions for drying rate, energy consumption, moisture ratio, and shrinkage [50]. Yüzgeç et al. [51] found that the overall performance of the ANFIS model was better than the other three models used based on mass and heat transfer, the mechanism of diffusion, and ANN. There is, however, no information on the modelling of sawdust drying. As was mentioned above, processed biofuels (pellets and briquettes) are produced from, inter alia, dry sawdust.

Some authors have described the effect of drying variables on the parameters of drying models; in these cases such models may be considered to be more general. In the literature, the predicted parameter values of drying models were correlated as a function of $T$ [52-54], $T$ and $v$ [55], characteristic particle dimension $(L)$ and initial material load [52], and $T, v$, $L$, and the initial height of the layer [56]. No information was obtained concerning the examination of the effects of $T$ and $v$ on the parameters of the drying models for sawdust.

The aim of the present study was to study sawdust drying kinetics in a convective dryer and the modelling of thin-layer drying of sawdust, investigate the effect of the drying air temperature and drying air velocity on the parameters of drying models, and indicate the equations describing this effect.

\section{Materials and Methods}

\subsection{Material}

Sawdust of spruce (Picea abies), beech (Fagus silvatica), willow (Salix alba), and alder (Alnus glutinosa) was used in the drying experiments. Spruce, beech, and alder were obtained from natural forest, and willow from an open area, both located in southern Poland (Beskid Żywiecki) $400 \mathrm{~m}$ above sea level. Willow trees were approximately 40 years old, whereas spruce, beech, and alder trees were approximately 60 years old. Trees were cut in January and then stored in an open area. After one month of storage, wood was transported to a sawmill located not far away, stored again in an open area for approximately one week, and then processed. The woody biomass used in our experiments was obtained from a sawmill. The wood particle size distribution was evaluated through screen analysis. Sawdust particles totaling $86 \%$ for spruce, $82 \%$ for beech, $84 \%$ for willow, and $77 \%$ for alder were passed through the $10 \mathrm{~mm}$ screen and were trapped in the $0.5 \mathrm{~mm}$ screen. The initial moisture content of samples ranged from 0.45 to $0.49 \mathrm{~kg} \mathrm{H} 2 \mathrm{O} / \mathrm{kg} \mathrm{d.m}$. (31-32.9\% w.b.) for spruce, 0.85 to $0.90 \mathrm{~kg} \mathrm{H} 2 \mathrm{O} / \mathrm{kg} \mathrm{d.m.} \mathrm{(45.9-47.4 \%} \mathrm{w.b.)} \mathrm{for} \mathrm{beech,} 0.77$ to $0.82 \mathrm{~kg}$ $\mathrm{H}_{2} \mathrm{O} / \mathrm{kg}$ d.m. (43.5-45.1\% w.b.) for willow, and 1.07 to $1.16 \mathrm{~kg} \mathrm{H} \mathrm{H}_{2} \mathrm{O} / \mathrm{kg} \mathrm{d.m.} \mathrm{(51.7-53.7 \%}$ w.b.) for alder.

\subsection{Drying Equipment and Experimental Procedure}

The drying experiments were conducted in two types of laboratory dryers: a Memmert UFP400 (MEMMERT GmbH +Co. KG, Schwabach, Germany), and a dryer constructed in the Department of Fundamental Engineering, Faculty of Production Engineering, Warsaw University of Life Sciences, Warsaw, Poland.

Experiments were performed to determine the effect of drying air temperature and airflow velocity on the dehydration characteristics of sawdust. The drying experiments 
were conducted at the air temperature of 25,60 , and $80{ }^{\circ} \mathrm{C}$ and airflow velocity of 0.01 , 0.15 , and $1.5 \mathrm{~m} / \mathrm{s}$. Experiments at 0.01 and $0.15 \mathrm{~m} / \mathrm{s}$ were carried out using the Mammert UFP400 dryer, whereas experiments at $1.5 \mathrm{~m} / \mathrm{s}$ were carried out using the dryer constructed in our Department.

\subsubsection{Drying in Memmert UFP400 (v: 0.01 and $0.15 \mathrm{~m} / \mathrm{s}$ )}

The sample was put on the tulle stretched on the metal frame (scale) and hung up to the WPX 650 electronic scales (RADWAG, Radom, Poland). The weighing accuracy was $\pm 1 \mathrm{mg}$. A computer connected to the scales recorded the mass of the dried sample every $60 \mathrm{~s}$. Measurements were recorded up to the point when no mass changes were recorded. Experiments were repeated thrice.

The temperature of air in the dryer was measured with $0.1{ }^{\circ} \mathrm{C}$ accuracy using a TP-01b-W3 thermocouple (NiCr-NiAl, CZAKI THERMO-PRODUCT, Raszyn, Poland), which was placed at the center of the dryer chamber. An EMT-08 m (CZAKI THERMOPRODUCT, Raszyn, Poland) was used to measure the temperature. The airflow velocity in the dryer was measured with $3 \%$ accuracy using a Kestrel ${ }^{\circledR} 4000$ Packet Weather ${ }^{\mathrm{TM}}$ Tracker $^{\mathrm{TM}}$ (Nielsen-Kellerman Company, Boothwyn, PA, USA).

\subsubsection{Drying in Laboratory Dryer (v: $1.5 \mathrm{~m} / \mathrm{s}$ )}

The laboratory dryer constructed in our Department has the following elements: an airflow control unit, an electrical fan, a heating and heating control unit, a drying chamber, and a measurement sensor. The drying air velocity and temperature were measured directly in the drying chamber. The samples were placed on a stainless steel wire tray of known weight. Samples were weighed manually outside the chamber.

Prior to placing the sample in the drying chamber, the system was run for at least $1 \mathrm{~h}$ to obtain steady conditions. Then the sample was put on the tray. The sample mass was measured every 15 min - the sample tray was weighed outside the chamber using an electronic balance (WPX 4500, RADWAG, Radom, Poland), which was next to the test chamber. The weighing accuracy was $\pm 10 \mathrm{mg}$. The weighing operation took only a few seconds. Drying was continued until no further changes in mass sample were observed. Experiments were replicated three times.

The drying air velocity was measured using an ANT-93 hot wire digital anemometer (PMP IMG PAN, Kraków, Poland) with an accuracy of $\pm 0.1 \mathrm{~m} / \mathrm{s}$, and the temperature using a TP-01b-W3 thermocouple (NiCr-NiAl, CZAKI THERMO-PRODUCT, Raszyn, Poland) with an accuracy of $\pm 0.1^{\circ} \mathrm{C}$. Temperature reading was done with an EMT-08 m (CZAKI THERMO-PRODUCT, Raszyn, Poland).

\subsubsection{Moisture Content}

The moisture content $M$ was determined using the following formula:

$$
M=\frac{m-m_{d . m}}{m_{d . m}}
$$

where $M$ is the moisture content, $\mathrm{kg} \mathrm{H}_{2} \mathrm{O} / \mathrm{kg} \mathrm{d.m.,} m$ is the mass of the sample, $\mathrm{g}$, and $m_{d . m}$. is the mass of dry matter in the sample, $\mathrm{g}$.

The initial and equilibrium moisture content of the samples $\left(M_{0}\right.$ and $\left.M_{\mathrm{e}}\right)$ were determined gravimetrically by drying in a laboratory oven at the temperature of $105{ }^{\circ} \mathrm{C}$ and atmospheric pressure for a period of $24 \mathrm{~h}$, until completely dry [57].

\subsection{Mathematical Modelling of Drying Curves}

Convection drying of biological products is a complex process which involves heat and mass transfer between the airflow and the product [47].

Various types of dryers are used for the drying of granular materials. The most common dryers applied now for biomass were discussed in Fagernäs et al. [28]. Depending on the type of dryer, the drying process of granular materials can be described as a thin- 
layer drying or deep bed drying. It has to be emphasized that most of the equations describing the thin-layer drying process can (through only one equation) describe deep bed drying. Thin-layer models do not describe the transfer processes in deep beds, because there are no gradients of temperature or moisture content within a thin-layer of granular material [58]. Such models, however, were sometimes used for predicting the deep bed drying. The deep bed of studied granular material was considered in such a case to be divided into a number of thin-layers [59,60]. When modelling the granular material drying process in a deep bed, the following variables need to be predicted with the progress of drying: the moisture content of a particle, the temperature of a particle, the humidity ratio of drying air in the bed, and the temperature of the drying air in the bed. Thus, a model of the granular material drying in a deep bed must comprise four differential equations, which are obtained from energy balances on air and particles, moisture balance on air, and the drying rate equation of a thin-layer of particles [61]. Therefore, the thin-layer equation is one of the equations in a system of equations used for modelling a deep bed granular material drying system $[38,58,62]$.

Summing up, it must be stressed that the knowledge of thin-layer models is necessary for mathematical modelling of convection drying of granular materials. As was stated, there is, however, no information on the thin-layer modelling of sawdust.

The moisture transfer inside the convection dried biological products can be assumed to be controlled by diffusion mechanisms. Therefore the following equation describes the drying of sawdust particles:

$$
\frac{\partial M}{\partial t}=D \nabla^{2} M
$$

where $t$ is the time, and $D$ is the moisture diffusion coefficient, $\mathrm{m}^{2} / \mathrm{s}$.

The following initial and boundary conditions were accepted: (i) the initial moisture content $M_{0}$ is the same at any point of dried solid at the beginning of drying, and (ii) the moisture content on the solid surface is equal to the equilibrium moisture content $M_{e}$.

Sawdust used in the drying experiments was composed of particles of different shapes. Some of them could be treated as an infinite plane, the other could be considered as a sphere.

Solving Equation (2) with the above-mentioned conditions with respect to mean moisture content as a function of time gives the following equations [61]:

- for an infinite plane of thickness $2 s$,

$$
\frac{M-M_{e}}{M_{0}-M_{e}}=\frac{8}{\pi^{2}} \sum_{n=0}^{\infty} \frac{1}{(2 n+1)^{2}} \exp \left(-\frac{\pi^{2}(2 n+1)^{2}}{4} \frac{D t}{s^{2}}\right)
$$

- for a sphere of radius $s$,

$$
\frac{M-M_{e}}{M_{0}-M_{e}}=\frac{6}{\pi^{2}} \sum_{n=0}^{\infty} \frac{1}{n^{2}} \exp \left(-n^{2} \pi^{2} \frac{D t}{s^{2}}\right)
$$

The above-obtained theoretical thin-layer models (Equations (3) and (4)) consider the fundamentals of the drying process, and their parameters have physical meaning. Therefore, they can explain the mechanism of the process. They need, however, an assumption of, for example, moisture diffusion coefficient and particle geometry.

Practical drying requires simple semi-theoretical and empirical thin-layer models. The semi-theoretical models are generally derived directly from the general solution of Fick's second law by simplification. The empirical models provide direct relationship between average moisture content and drying time. They however neglect the fundamentals of the drying process. Such models are easy to use, but their applications are restricted to only the range of drying conditions led during the experiment [63]. The discussed thin-layer models widely employed to describe the convection drying kinetics of such biological products as vegetables, fruits, seeds, and grains are shown in Table 1. Woody biomass also 
belongs to the biological products. Therefore, the models presented in Table 1 were used to describe the convection drying kinetics of sawdust.

Table 1. Semi-theoretical and empirical thin-layer models applied to drying curves of sawdust.

\begin{tabular}{|c|c|c|c|}
\hline Model No. & Model Equation & Model Name & References \\
\hline 1 & $\mathrm{MR}=\exp (-k t)$ & Lewis (Newton) & [64] \\
\hline 2 & $\mathrm{MR}=a \exp (-k t)$ & Henderson and Pabis & {$[65]$} \\
\hline 3 & $\mathrm{MR}=a \exp \left(-k_{1} t\right)+b$ & Logarithmic & [66] \\
\hline 4 & $\mathrm{MR}=a \exp \left(-k_{1} t\right)+b \exp \left(-k_{2} t\right)$ & Two-term & [67] \\
\hline 5 & $\mathrm{MR}=a \exp \left(-k_{1} t\right)+b \exp \left(-k_{2} t\right)+c$ & Noomhorm and Verma & [68] \\
\hline 6 & $\mathrm{MR}=a \exp \left(-k_{1} t\right)+b \exp \left(-k_{2} t\right)+c \exp \left(-k_{3} t\right)$ & Modified Henderson and Pabis & [69] \\
\hline 7 & $\mathrm{MR}=a \exp (-k t)+(1-a) \exp (-a k t)$ & Two-term exponential & [70] \\
\hline 8 & $\mathrm{MR}=a \exp (-k t)+(1-a) \exp (-g t)$ & Verma et al. & [71] \\
\hline 9 & $\mathrm{MR}=\exp \left(-k t^{n}\right)$ & Page & [72] \\
\hline 10 & $\mathrm{MR}=a \exp \left(-k t^{n}\right)$ & Kaleta et al. I & {$[53]$} \\
\hline 11 & $\mathrm{MR}=a \exp \left(-k t^{n}\right)+b \exp \left(-g t^{n}\right)$ & Hii et al. & [73] \\
\hline 12 & $\mathrm{MR}=a \exp \left(-k t^{n}\right)+(1-a) \exp \left(-g t^{n}\right)$ & Kaleta et al. II & [53] \\
\hline 13 & $\mathrm{MR}=\exp \left[-(k t)^{n}\right]$ & Modified Page & [74] \\
\hline 14 & $\mathrm{MR}=a \exp \left[-(k t)^{n}\right]$ & Ademiluyi & [75] \\
\hline 15 & $\mathrm{MR}=a \exp \left[-(k t)^{n}\right]+b$ & Demir et al. & [76] \\
\hline 16 & $\mathrm{MR}=a \exp \left[-(k t)^{n}\right]+b \exp \left[-(g t)^{n}\right]$ & Kaleta et al. III & [53] \\
\hline 17 & $\mathrm{MR}=1+a t+b t^{2}$ & Wang and Singh & [77] \\
\hline 18 & $\mathrm{MR}=a \exp \left(-k t^{n}\right)+b t$ & Midilli et al. & [78] \\
\hline
\end{tabular}

$a, b, c, g, n-$ constants of models, $-, k, k_{1}, k_{2}, k_{3}$-drying rate constants, $1 / \mathrm{s}$.

The drying curves of sawdust obtained from experiments were converted into dimensionless moisture content MR (moisture ratio):

$$
\mathrm{MR}=\frac{M-M_{e}}{M_{0}-M_{e}} .
$$

Drying rate was determined using the following equation:

$$
\text { Drying rate }=\frac{M_{t+\mathrm{d} t}-M_{t}}{d_{t}}
$$

where $M_{t}$ is the moisture content at $t$, and $M_{t+\mathrm{d} t}$ is the moisture content at $t+\mathrm{d} t$.

Drying curves were fitted to twenty different models (Table 1 and Equations (3) and (4)). A non-linear regression analysis was conducted to fit the models by the LavenbergMarquardt method using the computer program STATISTICA 10 [79].

The goodness of fit of the tested mathematical models that were tested to the experimental data was assessed using the correlation coefficient $(R)$, the root mean square error (RMSE), and reduced chi-square $\left(\chi^{2}\right)$. With the higher $R$ value, the RMSE and $\left(\chi^{2}\right)$ values were lower, and the goodness of fit was better $[53,80,81]$.

The effects of drying air temperature and airflow velocity on the models 1-18 constants and coefficients were determined by investigating the following type of equations: linear, $Y=A+B T+C v$; rational, $Y=A+B / T+C / v$; logarithmic (natural), $Y=A+B \ln (T)+C \ln (v)$; logarithmic (common), $Y=A+B \log (T)+C \log (v)$; and square, $Y=A+B T+C v+D T^{2}+$ $E T v+F v^{2}$, where $Y$ is the variable, and $A, B, C, D, E$, and $F$ are the coefficients. The goodness of fit of the tested equations that were tested to the experimental data was assessed using $R$, RMSE, and $\chi^{2}$.

The moisture diffusion coefficient depends strongly on temperature $[61,82,83]$. The moisture diffusion coefficient of the models 19 and 20 (Equation (3) is described as model 19, and Equation (4) is described as model 20) involving the mentioned drying variable was described by following equation: $D / L^{2}=A+B T$, where $A, B$ are the coefficients, $L=s$ for an infinite plane of thickness $2 s$, and $L=s$ for a sphere of radius $s$. The goodness of the tested equation fit was assessed using $R$, RMSE, and $\chi^{2}$. 


\section{Results and Discussion}

\subsection{Drying Characteristics}

The sawdust drying was affected by drying air temperature and airflow velocity (Figure 1). Each of the drying curves represents an empirical formula that approximates results of the three measurement repetitions of the moisture content changes in time. The drying rate curves were obtained by differentiation of the drying curve. For the purpose of clarify of the diagrams in Figure 1, measurement points and confidence regions were not marked.

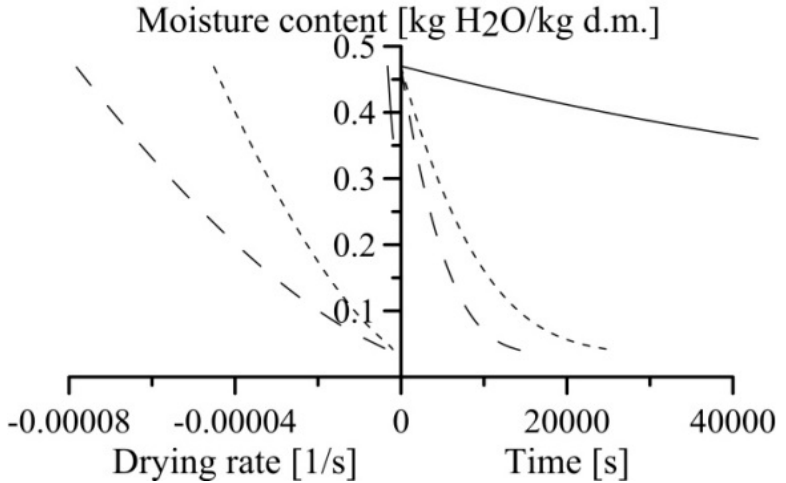

(a)

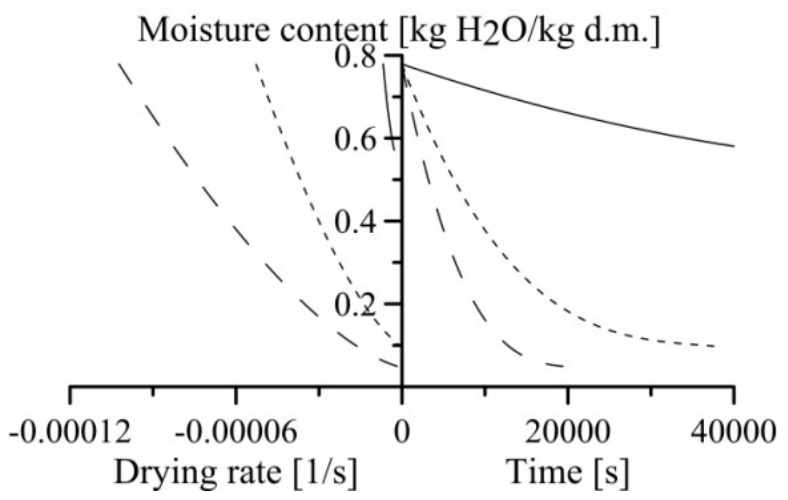

(c)

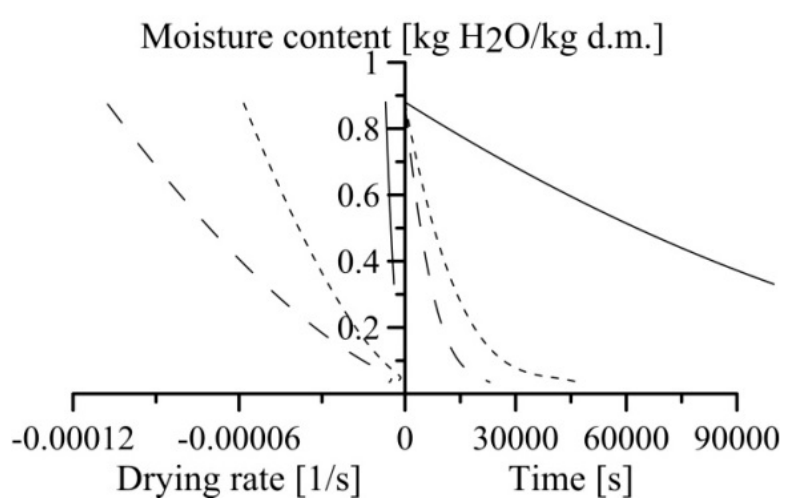

(b)

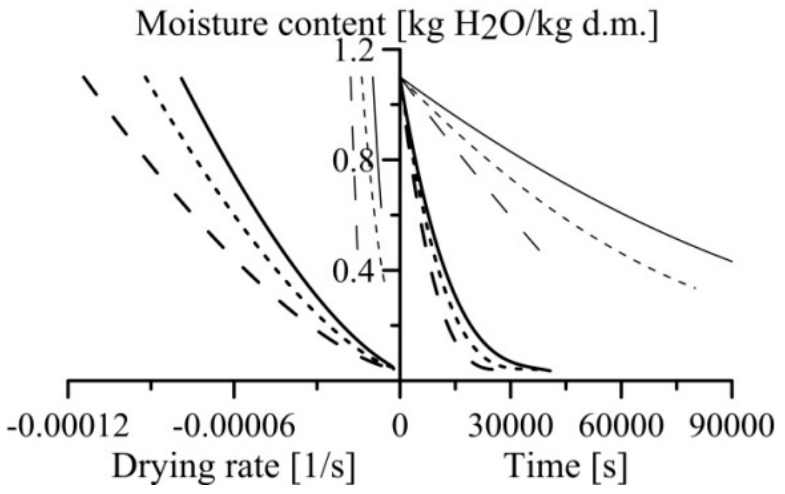

(d)

Figure 1. Moisture content versus time and drying rate versus moisture content for drying of (a) spruce, (b) beech, (c) willow sawdust at $0.01 \mathrm{~m} / \mathrm{s}$ and at air temperatures; (_- $25^{\circ} \mathrm{C},(---) 60^{\circ} \mathrm{C},(--) 80^{\circ} \mathrm{C}$, and alder (d) sawdust at different air temperatures and velocities; (- $25^{\circ} \mathrm{C}, 0.01 \mathrm{~m} / \mathrm{s},(--) 25^{\circ} \mathrm{C}, 0.15 \mathrm{~m} / \mathrm{s},(-\longrightarrow) 25^{\circ} \mathrm{C}, 1.5 \mathrm{~m} / \mathrm{s},(-) 60{ }^{\circ} \mathrm{C}$, $0.01 \mathrm{~m} / \mathrm{s},(--) 60{ }^{\circ} \mathrm{C}, 0.15 \mathrm{~m} / \mathrm{s},(--) 60^{\circ} \mathrm{C}, 1.5 \mathrm{~m} / \mathrm{s}$.

The drying measurements were carried at the air temperatures of 25,60 , and $80^{\circ} \mathrm{C}$ and airflow velocities of $0.01,0.15$, and $1.5 \mathrm{~m} / \mathrm{s}$. Similar conditions for woody biomass drying can be found in the literature. Bauer [84] stated that wood drying is classified in "lowtemperature-drying" at temperatures between 15 and $45^{\circ} \mathrm{C}$, "normal-temperature-drying" at temperatures between 45 and $90^{\circ} \mathrm{C}$, and "high-temperature-drying" at temperatures between 90 and $130^{\circ} \mathrm{C}$. Low-temperature-drying results in good drying quality but also in relatively long drying times. High-temperature-drying has negative impact on the wood characteristics, and for that reason it is used only in special cases. The normal-temperaturedrying is the most common method of artificial drying. Gigler et al. [41] investigated the forced convective drying of willow chips at $20^{\circ} \mathrm{C}$. The air velocity varied between 0.1 and $0.2 \mathrm{~m} / \mathrm{s}$. Gigler et al. [6] conducted natural wind drying experiments of willow chunks. The average air velocity was assumed as $0.2 \mathrm{~m} / \mathrm{s}$. Ståhl et al. [17] dried the sawdust and cutter shavings from Norwegian spruce and Scottish pine at temperatures of $60-82{ }^{\circ} \mathrm{C}$, 
whereas Kobayashi et al. [24] investigated the drying behavior of sawdust and the woody powder at $70{ }^{\circ} \mathrm{C}$. Particles of Norway spruce $\left(20 \times 20 \times 5 \mathrm{~mm}^{3}\right)$ were dried at two different air temperatures, $70^{\circ} \mathrm{C}$ and $120^{\circ} \mathrm{C}$, and at an air velocity of $0.6 \mathrm{~m} / \mathrm{s}$ [14], while particles $\left(50 \times 100 \mathrm{~mm}^{2}\right)$ of the same wood species were dried at 60 and $100{ }^{\circ} \mathrm{C}$ and at $2 \mathrm{~m} / \mathrm{s}$ [21]. Lerman and Wennberg [27] studied the bed drying of woody biomass (Norway spruce wood chips and sawdust). The air temperature varied between 50 and $90{ }^{\circ} \mathrm{C}$, and the air velocity lay within the range of 0.16 to $1 \mathrm{~m} / \mathrm{s}$.

As can be seen (Figure 1), moisture content and drying rate decreased with drying time. The drying temperature played an important role in the drying process. It can be observed that the higher the air temperature, the shorter the drying time and the higher the drying rate. For constant air velocity of $0.01 \mathrm{~m} / \mathrm{s}$, the drying time required to reach the moisture content of $0.4 \mathrm{~kg} \mathrm{H} \mathrm{H}_{2} \mathrm{O} / \mathrm{kg} \mathrm{d}$.m. for beech sawdust was reduced 7.75 times as drying temperature increased from 25 to $60^{\circ} \mathrm{C}$ and 13.78 times as drying temperature increased from 25 to $80{ }^{\circ} \mathrm{C}$ (Figure $1 \mathrm{~b}$ ). In case of alder sawdust (Figure 1d), the drying time required to reach the moisture content of $0.4 \mathrm{~kg} \mathrm{H} \mathrm{H}_{2} \mathrm{O} / \mathrm{kg} \mathrm{d}$.m. was shortened 6.5 times as drying temperature increased from 25 to $60^{\circ} \mathrm{C}$ (for constant air velocity of $0.15 \mathrm{~m} / \mathrm{s}$ ). In the case of spruce sawdust (Figure 1a) and willow sawdust (Figure 1c), the drying time required to reach the moisture content of $0.1 \mathrm{~kg} \mathrm{H} \mathrm{H}_{2} \mathrm{O} / \mathrm{kg} \mathrm{d.m}$. was reduced 1.78 and 2.61 times, respectively, as drying temperature increased from 60 to $80{ }^{\circ} \mathrm{C}$ (for constant air velocity of $0.01 \mathrm{~m} / \mathrm{s}$ ). The following explanation of the obtained results can be offered. Water molecules moved faster due to enhanced heat transfer rate with the increase of drying temperature, which subsequently accelerated the moisture migration inside the product. Higher drying rate in the initial period of drying was the result of less external resistance as well as greater migration of inner water. Lower drying rate observed at the last stage of drying can be explained by the low value of moisture diffusion coefficient in the latter stage of the drying process $[85,86]$. The decrease in drying time and increase in drying rate with increasing drying temperature have been noticed for wood particles of Norwegian spruce [14,21], and particle of Scottish pine [84], germinated brown rice [87], potato slices [88], and yacon slices [86].

The airflow velocity had an effect on drying rates of sawdust (Figure 1d). For a constant drying temperature of $25^{\circ} \mathrm{C}$, the drying time required to reach the moisture content of $0.4 \mathrm{~kg} \mathrm{H} \mathrm{H}_{2} \mathrm{O} / \mathrm{kg} \mathrm{d.m}$. was shortened 1.36 times as air velocity increased from 0.01 to $0.15 \mathrm{~m} / \mathrm{s}$ and 2.26 times as air velocity increased from 0.01 to $1.5 \mathrm{~m} / \mathrm{s}$. For constant drying temperature of $60{ }^{\circ} \mathrm{C}$, the drying time required to reach the same value of alder sawdust moisture content was shortened 1.58 times, as air velocity increased from 0.01 to $1.5 \mathrm{~m} / \mathrm{s}$. For a constant drying temperature of $60^{\circ} \mathrm{C}$, the drying time required to reach the moisture content of $0.1 \mathrm{~kg} \mathrm{H} \mathrm{H}_{2} \mathrm{O} / \mathrm{kg}$ d.m. was reduced 1.25 times as air velocity increased from 0.01 to $0.15 \mathrm{~m} / \mathrm{s}$, and 1.67 times as air velocity increased from 0.01 to $1.5 \mathrm{~m} / \mathrm{s}$. The moisture content changes of the alder sawdust by varying the airflow velocity at constant air temperature were less pronounced than those that appeared while varying the air temperature at constant airflow velocity. Similar trends were observed for sawdust of spruce, beech, and willow. The obtained results were in agreement with the observations of Bauer [84] for sugar maple wood, Shi et al. [86] for yacon slices, and Pangavhane et al. [89] for seedless grapes. Toğrul and Pehlivan [90] for single apricot and Kaleta and Górnicki [56] for slices and cubes of apple found, however, that the influence of airflow velocity on drying rate was greater than the influence of air temperature.

The effect of the drying air temperature and airflow velocity on the decrease of moisture content of sawdust during drying were analyzed using the analysis of variance (ANOVA) with application of the uniformity Lavene's test variance. Tukey's test HDS was applied for division into uniform groups (at the significance level of $p=0.05$ ). The computations were performed using STATISTICA 10 software.

Statistical analysis of the effect of the drying air temperature and airflow velocity on decrease of sawdust moisture content during drying (division into uniform groups) are shown in Table 2. In the table, quantities are given as a mean from three repetitions \pm 
standard deviation, whereas uniforms groups for each time of drying are denoted with the same letters. As can be seen, the effect of drying air temperature on the decrease of sawdust moisture content during drying was statistically significant. It can be accepted that the influence of airflow velocity on the decrease of moisture content became statistically significant after $4 \mathrm{~h}$ of sawdust drying at $25^{\circ} \mathrm{C}$ and after $1 \mathrm{~h}$ of drying at $60^{\circ} \mathrm{C}$.

Table 2. Moisture content ( $\mathrm{kg} \mathrm{H} \mathrm{H}_{2} \mathrm{O} / \mathrm{kg}$ d.m.) of sawdust (with standard deviation) in the drying process.

\begin{tabular}{|c|c|c|c|c|c|}
\hline \multirow{2}{*}{ Material } & \multirow{2}{*}{ Conditions of Drying } & \multicolumn{4}{|c|}{ Time (h) } \\
\hline & & 1 & 2 & 4 & 8 \\
\hline \multirow{3}{*}{ Spruce } & $25^{\circ} \mathrm{C}, 0.01 \mathrm{~m} / \mathrm{s}$ & $0.45 \pm 0.04 b c$ & $0.44 \pm 0.04 b$ & $0.42 \pm 0.04 \mathrm{e}$ & $0.39 \pm 0.04 b$ \\
\hline & $60^{\circ} \mathrm{C}, 0.01 \mathrm{~m} / \mathrm{s}$ & $0.32 \pm 0.03 \mathrm{ab}$ & $0.22 \pm 0.03 a$ & $0.09 \pm 0.03 a$ & \\
\hline & $80^{\circ} \mathrm{C}, 0.01 \mathrm{~m} / \mathrm{s}$ & $0.24 \pm 0.03 a$ & $0.11 \pm 0.03 a$ & $0.04 \pm 0.03 \mathrm{a}$ & \\
\hline \multirow{3}{*}{ Beech } & $25^{\circ} \mathrm{C}, 0.01 \mathrm{~m} / \mathrm{s}$ & $0.85 \pm 0.05 f$ & $0.83 \pm 0.05 \mathrm{ef}$ & $0.78 \pm 0.05 \mathrm{fg}$ & $0.69 \pm 0.05 c$ \\
\hline & $60^{\circ} \mathrm{C}, 0.01 \mathrm{~m} / \mathrm{s}$ & $0.68 \pm 0.05$ de & $0.52 \pm 0.04 b c$ & $0.29 \pm 0.03 d$ & $0.08 \pm 0.03 a$ \\
\hline & $80^{\circ} \mathrm{C}, 0.01 \mathrm{~m} / \mathrm{s}$ & $0.69 \pm 0.04 \mathrm{de}$ & $0.42 \pm 0.03 b$ & $0.13 \pm 0.03 \mathrm{ab}$ & \\
\hline \multirow{3}{*}{ Willow } & $25^{\circ} \mathrm{C}, 0.01 \mathrm{~m} / \mathrm{s}$ & $0.75 \pm 0.05 \mathrm{def}$ & $0.73 \pm 0.05 \mathrm{de}$ & $0.69 \pm 0.05 f$ & $0.62 \pm 0.04 c$ \\
\hline & $60^{\circ} \mathrm{C}, 0.01 \mathrm{~m} / \mathrm{s}$ & $0.60 \pm 0.04 \mathrm{~cd}$ & $0.46 \pm 0.04 b$ & $0.27 \pm 0.03 c d$ & \\
\hline & $80^{\circ} \mathrm{C}, 0.01 \mathrm{~m} / \mathrm{s}$ & $0.46 \pm 0.04 \mathrm{bc}$ & $0.26 \pm 0.03 a$ & $0.07 \pm 0.03 a$ & \\
\hline \multirow{6}{*}{ Alder } & $25^{\circ} \mathrm{C}, 0.01 \mathrm{~m} / \mathrm{s}$ & $1.06 \pm 0.06 \mathrm{~g}$ & $1.03 \pm 0.06 \mathrm{~g}$ & $0.96 \pm 0.05 \mathrm{~h}$ & $0.83 \pm 0.05 \mathrm{~d}$ \\
\hline & $25^{\circ} \mathrm{C}, 0.15 \mathrm{~m} / \mathrm{s}$ & $1.05 \pm 0.06 \mathrm{~g}$ & $1.00 \pm 0.06 \mathrm{~g}$ & $0.91 \pm 0.05 \mathrm{gh}$ & $0.74 \pm 0.05 \mathrm{~cd}$ \\
\hline & $25^{\circ} \mathrm{C}, 1.5 \mathrm{~m} / \mathrm{s}$ & $1.03 \pm 0.06 \mathrm{~g}$ & $0.97 \pm 0.05 \mathrm{fg}$ & $0.84 \pm 0.05 \mathrm{gh}$ & $0.61 \pm 0.04 c$ \\
\hline & $60^{\circ} \mathrm{C}, 0.01 \mathrm{~m} / \mathrm{s}$ & $0.83 \pm 0.05 \mathrm{ef}$ & $0.62 \pm 0.04 \mathrm{~cd}$ & $0.32 \pm 0.03 \mathrm{de}$ & \\
\hline & $60^{\circ} \mathrm{C}, 0.15 \mathrm{~m} / \mathrm{s}$ & $0.80 \pm 0.05 \mathrm{ef}$ & $0.56 \pm 0.04 b c$ & $0.25 \pm 0.03 \mathrm{bcd}$ & \\
\hline & $60^{\circ} \mathrm{C}, 1.5 \mathrm{~m} / \mathrm{s}$ & $0.73 \pm 0.05 \mathrm{def}$ & $0.47 \pm 0.04 \mathrm{~b}$ & $0.15 \pm 0.03 \mathrm{abc}$ & \\
\hline
\end{tabular}

$\mathrm{a}, \mathrm{b}, \mathrm{c}, \mathrm{d}, \mathrm{e}, \mathrm{f}, \mathrm{g}, \mathrm{h}$ - the same letters in the same column denote groups that do not differ significantly at level $p=0.05$.

\subsection{Evaluation of the Models}

The examined drying models were evaluated in the following way. The data related to moisture content obtained for the different drying air temperatures and airflow velocities were converted to the dimensionless moisture content expression (Equation (4)). Next, curve fitting computations with the drying time were carried on the models. A non-linear regression analysis was conducted. On its basis, the constants and coefficients of the models were determined. The $R, \mathrm{RMSE}$, and $\chi^{2}$ were calculated, and on their basis, the goodness of fit of the tested mathematical models that were tested to the experimental data was assessed. As far as semi-theoretical and empirical models 1-18 were concerned, the statistical analysis results were satisfying for all considered kinds of sawdust. The values of coefficients were as follows: $R=0.9819-1$, RMSE $=0-0.1427, \chi^{2}=0-0.0204$ for spruce, $R=0.9828-1$, RMSE $=0-0.0654, \chi^{2}=0-0.015$ for beech, $R=0.9896-1$, RMSE $=0-0.1668$, $\chi^{2}=0-0.0034$ for willow, and $R=0.9763-1$, RMSE $=0-0.0761, \chi^{2}=0-0.0057$ for alder.

Further regressions were undertaken to account for the effect of the drying air temperature and airflow velocity on the semi-theoretical and empirical model parameters. The eighteen considered models were used to describe the drying process of sawdust particles of spruce, beech, willow, and alder. The effects of drying air temperature and airflow velocity on the parameters were also included in the models. The linear, rational, logarithmic (natural), logarithmic (common), and square type of equations were tested. The mentioned equation types for the description of the constants and coefficients were included in the final models. Based on the nonlinear regression analysis, constants of the parameter equations were determined. The considered equations with the determined coefficients were then used to estimate the changes of sawdust moisture content during the process. The values of R, RMSE, and $\chi 2$ were calculated. Validation of the established models was made by comparing the computed moisture content with the measured ones in any particular drying run. The statistical analyses gave the following results: Models $2,7,8$, and 14 (Table 1) with the model parameters determined with rational and both logarithmic equations can be considered as the most appropriate for spruce. When model 
parameters were calculated using linear and square equations it can be assumed that models 13 and 18 gave the best results for spruce. Taking into account values of $R$, RMSE, and $\chi^{2}$, it can be accepted that models 2, 4, and 11 with the model parameters determined using linear, rational, and both logarithmic equations can be treated as the most suitable ones to describe the drying characteristics of beech sawdust. Models 4, 5, and 7 with the model parameters calculated using linear, rational, and both logarithmic equations can be chosen as the best for describing the drying of willow sawdust (Table 3). Models 2, 4, 7 , and 13 with the model parameters determined using all considered equations can be considered as the most appropriate for alder. The evaluation of the theoretical models 19 and 20 (Equation (2) is described as model 19 and Equation (3) is described as model 20) gave the following results: The values of $D / L^{2}$ determined from models 19 and 20 were found to be between $6.47 \times 10^{-5}\left(\right.$ at $25^{\circ} \mathrm{C}$ ) and $4.58 \times 10^{-3} 1 / \mathrm{s}\left(\right.$ at $\left.80^{\circ} \mathrm{C}\right)$. These values are comparable to those reported in the literature data. Garcia-Pascual et al. [91] stated that for Boletus edulis mushrooms, $D / L^{2}$ ranged from $4.9 \times 10^{-4}$ (at $25^{\circ} \mathrm{C}$ ) to $9.4 \times 10^{-4} 1 / \mathrm{s}$ (at $70{ }^{\circ} \mathrm{C}$ ). Garcia-Pascual et al. [92] found that for Marchella esculenta mushrooms, $D / L^{2}$ varied between $1.06 \times 10^{-3}$ (at $25^{\circ} \mathrm{C}$ ) and $1.44 \times 10^{-3} 1 / \mathrm{s}$ (at $70^{\circ} \mathrm{C}$ ). It was confirmed that the moisture diffusion coefficient increased with increased drying air temperature. Similar observation were reported by other researchers $[53,63,81,93]$. Further regressions were undertaken to account for the effect of the drying air temperature on the $D / L^{2}$. The effect of drying air temperature on the $D / L^{2}$ was also included in models 19 and 20 . The linear type of equation was tested. The multiple combination of the parameters that gave the highest $R$-values were included in the final model. The considered equation with the determined coefficients were then applied to estimate the moisture content of sawdust at any time during the process. Validation of the established models was made by comparing the computed moisture contents with the measured ones in any particular drying run. The results of statistical analyses are shown in Table 4. It can be noticed that the theoretical model of an infinite plane drying (model 19) gave better results for all examined kinds of sawdust compared to the theoretical model of sphere drying (model 20).

Table 3. Parameter equation coefficients for selected semi-theoretical and empirical models of sawdust drying, and comparison of results of statistical analyses regarding modelling of willow dried at air temperature of $60^{\circ} \mathrm{C}$ and airflow velocity of $0.01 \mathrm{~m} / \mathrm{s}$.

\begin{tabular}{|c|c|c|c|c|c|c|c|c|}
\hline \multirow{2}{*}{ Model No. } & \multirow{2}{*}{$\begin{array}{l}\text { Type of Parameter } \\
\text { Equation }\end{array}$} & \multicolumn{3}{|c|}{ Parameter Equation Coefficients } & \multirow{2}{*}{ Parameter } & \multirow{2}{*}{$R$} & \multirow{2}{*}{ RMSE } & \multirow{2}{*}{$\chi^{2}$} \\
\hline & & A & B & $\mathrm{C}$ & & & & \\
\hline \multirow{4}{*}{4} & $\mathrm{~L}$ & $\begin{array}{l}-0.47612 \\
-0.01618 \\
-0.10423 \\
-0.01521\end{array}$ & $\begin{array}{c}0.03182 \\
0.00017 \\
-0.03171 \\
0.00014\end{array}$ & $\begin{array}{c}-72.40853 \\
1.02927 \\
230.99235 \\
1.13035\end{array}$ & $\begin{array}{c}a=0.70887 \\
k_{1}=0.00425 \\
b=0.30290 \\
k_{2}=0.00457\end{array}$ & 0.998 & 0.091 & 0.008 \\
\hline & $\mathrm{R}$ & $\begin{array}{l}0.52554 \\
0.02222 \\
5.97768 \\
0.06247\end{array}$ & $\begin{array}{c}-95.75608 \\
-0.46294 \\
95.18170 \\
-0.38511\end{array}$ & $\begin{array}{c}-72.40853 \\
1.02927 \\
230.99235 \\
1.13035\end{array}$ & $\begin{array}{c}a=1.52489 \\
k_{1}=0.00849 \\
b=-0.50984 \\
k_{2}=0.00810\end{array}$ & 0.978 & 0.100 & 0.010 \\
\hline & $\mathrm{Ln}$ & $\begin{array}{c}3.00751 \\
0.01312 \\
-2.11214 \\
0.01678\end{array}$ & $\begin{array}{c}2.04886 \\
0.01083 \\
-2.03906 \\
0.00905\end{array}$ & $\begin{array}{c}0.02595 \\
-0.00006 \\
-0.08074 \\
-0.00048\end{array}$ & $\begin{array}{c}a=1.13719 \\
k_{1}=0.00654 \\
b=-0.12426 \\
k_{2}=0.00647\end{array}$ & 0.995 & 0.040 & 0.002 \\
\hline & Lc & $\begin{array}{c}-9.22934 \\
0.00942 \\
-1.09934 \\
-0.01197\end{array}$ & $\begin{array}{c}4.71767 \\
0.02495 \\
-4.69511 \\
0.02083\end{array}$ & $\begin{array}{c}2.22772 \\
0.01106 \\
-2.24454 \\
0.01028\end{array}$ & $\begin{array}{c}a=1.13719 \\
k_{1}=0.00654 \\
b=-0.12426 \\
k_{2}=0.00647\end{array}$ & 0.995 & 0.040 & 0.002 \\
\hline
\end{tabular}


Table 3. Cont.

\begin{tabular}{|c|c|c|c|c|c|c|c|c|}
\hline \multirow{2}{*}{ Model No. } & \multirow{2}{*}{$\begin{array}{l}\text { Type of Parameter } \\
\text { Equation }\end{array}$} & \multicolumn{3}{|c|}{ Parameter Equation Coefficients } & \multirow{2}{*}{ Parameter } & \multirow{2}{*}{$R$} & \multirow{2}{*}{ RMSE } & \multirow{2}{*}{$x^{2}$} \\
\hline & & A & B & $\mathrm{C}$ & & & & \\
\hline \multirow{20}{*}{5} & \multirow{5}{*}{$\mathrm{L}$} & 1.18054 & 0.02686 & -244.23485 & $a=0.34993$ & \multirow{5}{*}{0.999} & \multirow{5}{*}{0.109} & \multirow{5}{*}{0.012} \\
\hline & & -0.01414 & 0.00013 & 1.19220 & $k_{1}=0.00532$ & & & \\
\hline & & 2.37032 & -0.03477 & 59.89724 & $b=0.88299$ & & & \\
\hline & & -0.04351 & 0.00005 & 4.51495 & $k_{2}=0.00486$ & & & \\
\hline & & -0.02425 & 0.00788 & -66.74356 & $c=-0.21868$ & & & \\
\hline & \multirow{5}{*}{$\mathrm{R}$} & 1.08304 & -78.70977 & 0.01263 & $a=1.03397$ & \multirow{5}{*}{0.978} & \multirow{5}{*}{0.104} & \multirow{5}{*}{0.011} \\
\hline & & 0.00585 & -0.40595 & 0.00010 & $k_{1}=0.00860$ & & & \\
\hline & & -2.52352 & 105.44911 & 0.00755 & $b=-0.01063$ & & & \\
\hline & & -0.01468 & -0.23236 & 0.00025 & $k_{2}=0.00640$ & & & \\
\hline & & -0.19371 & -27.15350 & 0.00638 & $c=-0.00864$ & & & \\
\hline & \multirow{5}{*}{ Ln } & -2.02610 & 1.77418 & 0.98370 & $a=0.70789$ & \multirow{5}{*}{0.996} & \multirow{5}{*}{0.103} & \multirow{5}{*}{0.011} \\
\hline & & -0.04502 & 0.00874 & -0.00351 & $k_{1}=0.00696$ & & & \\
\hline & & 3.08442 & -2.33462 & -1.49768 & $b=0.42275$ & & & \\
\hline & & 0.00825 & 0.00439 & 0.00450 & $k_{2}=0.00551$ & & & \\
\hline & & -0.76611 & 0.56400 & 0.36053 & $c=-0.11718$ & & & \\
\hline & \multirow{5}{*}{ Lc } & -3.10616 & 4.08520 & 1.72503 & $a=0.70789$ & \multirow{5}{*}{0.996} & \multirow{5}{*}{0.103} & \multirow{5}{*}{0.011} \\
\hline & & -0.01181 & 0.02013 & 0.00852 & $k_{1}=0.00696$ & & & \\
\hline & & 2.70636 & -5.37567 & -3.63758 & $b=0.42275$ & & & \\
\hline & & 0.00700 & 0.01011 & 0.00974 & $k_{2}=0.00551$ & & & \\
\hline & & -0.34452 & 1.29866 & 1.04094 & $c=-0.11718$ & & & \\
\hline \multirow{7}{*}{7} & & 2.70189 & -0.00751 & -54.25145 & $a=1.70857$ & \multirow{2}{*}{0.994} & \multirow{2}{*}{0.044} & \multirow{2}{*}{0.002} \\
\hline & L & 0.01411 & 0.00011 & -1.20281 & $k=0.00893$ & & & \\
\hline & \multirow{2}{*}{$\mathrm{R}$} & 0.88426 & 19.42966 & 0.00315 & $a=1.52317$ & \multirow{2}{*}{0.961} & 0133 & م018 \\
\hline & & 0.02428 & -0.38425 & -0.00006 & $k=0.01195$ & & 0.133 & 0.018 \\
\hline & & 0.42531 & -0.46806 & -0.67255 & $a=1.60614$ & & 0094 & \\
\hline & Ln & -0.00316 & 0.00814 & 0.00429 & $k=0.01040$ & 0.980 & 0.094 & 0.009 \\
\hline & Lc & 2.86410 & -1.07774 & -0.32922 & $a=1.60614$ & 0.980 & 0.0948 & 0.009 \\
\hline
\end{tabular}

L-linear, R—rational, Ln—logarithmic (natural), Lc-logarithmic (common).

Table 4. Coefficients of parameter equation $\left(D / L^{2}\right)$ for theoretical models of sawdust drying, and comparison of results of statistical analyses on the modelling of spruce, beech, willow, and alder.

\begin{tabular}{|c|c|c|c|c|c|c|}
\hline \multirow{2}{*}{ Kind of Sawdust } & \multirow{2}{*}{ Model } & \multicolumn{2}{|c|}{ Coefficients of Parameter Equation } & \multirow{2}{*}{$R$} & \multirow{2}{*}{ RMSE } & \multirow{2}{*}{$x^{2}$} \\
\hline & & A & B & & & \\
\hline \multirow{2}{*}{ Spruce } & Ip & -0.0012 & $7 \times 10^{-5}$ & $0.912-0.970$ & $0.132-0.280$ & $0.004-0.050$ \\
\hline & S & -0.0002 & $10^{-5}$ & $0.876-0.950$ & $0.167-0.301$ & $0.030-0.070$ \\
\hline \multirow{2}{*}{ Beech } & Ip & -0.0026 & $8 \times 10^{-5}$ & $0.900-0.974$ & $0.066-0.2405$ & $0.004-0.054$ \\
\hline & S & -0.0005 & $2 \times 10^{-5}$ & $0.627-0.953$ & $0.159-0.451$ & $0.026-0.157$ \\
\hline \multirow{2}{*}{ Willow } & Ip & -0.0026 & $8 \times 10^{-5}$ & $0.937-0.972$ & $0.075-0.250$ & $0.006-0.013$ \\
\hline & $\mathrm{S}$ & -0.0006 & $2 \times 10^{-5}$ & $0.754-0.956$ & $0.160-0.334$ & $0.026-0.112$ \\
\hline \multirow[b]{2}{*}{ Alder } & Ip & -0.0008 & $5 \times 10^{-5}$ & $0.907-0.974$ & $0.127-0.238$ & $0.007-0.057$ \\
\hline & $\mathrm{S}$ & -0.0002 & $10^{-5}$ & $0.741-0.964$ & $0.155-0.340$ & $0.024-0.121$ \\
\hline
\end{tabular}

Ip—infinite plane, S-sphere.

The effect of drying air temperature on the $D / L^{2}$ determined from both theoretical models and for all examined kind of sawdust can be determined using the following equation:

$$
D / L^{2}=3 \times 10^{-5} T
$$


Increasing the drying temperature resulted in the increase of the diffusion coefficient (Equation (7)). Increasing the diffusion coefficient resulted in the increase of the MR (Equation (3)), thus increasing the rate of drying (Figure 1).

The comparison of results of statistical analyses on the modelling of spruce and alder drying using both theoretical models and moisture diffusion coefficient determined by Equation (7) is presented in Table 5. Similar trends were shown in all experiments. It can be seen that at 25,60 , and $80^{\circ} \mathrm{C}$, the theoretical model of an infinitive plane represented the drying kinetics of all examined kinds of sawdust better than the theoretical model of a sphere.

Table 5. Comparison of results of statistical analyses on the modeling of spruce and alder drying using theoretical models and moisture diffusion coefficient determined by Equation (7).

\begin{tabular}{|c|c|c|c|c|c|c|c|c|}
\hline \multirow{2}{*}{ Kind of Sawdust } & \multicolumn{2}{|c|}{ Drying Variables } & \multicolumn{3}{|c|}{ Infinite Plane } & \multicolumn{3}{|c|}{ Sphere } \\
\hline & $v(\mathrm{~m} / \mathrm{s})$ & $T\left({ }^{\circ} \mathrm{C}\right)$ & $R$ & RMSE & $x^{2}$ & $R$ & RMSE & $x^{2}$ \\
\hline \multirow{7}{*}{ Spruce } & \multirow{3}{*}{0.01} & 25 & 0.926 & 0.115 & 0.013 & 0.836 & 0.361 & 0.130 \\
\hline & & 60 & 0.969 & 0.125 & 0.016 & 0.887 & 0.242 & 0.059 \\
\hline & & 80 & 0.965 & 0.192 & 0.037 & 0.929 & 0.202 & 0.041 \\
\hline & \multirow{2}{*}{0.15} & 25 & 0.926 & 0.186 & 0.025 & 0.668 & 0.402 & 0.133 \\
\hline & & 60 & 0.972 & 0.141 & 0.020 & 0.912 & 0.179 & 0.032 \\
\hline & \multirow{2}{*}{1.5} & 25 & 0.930 & 0.118 & 0.012 & 0.782 & 0.390 & 0.150 \\
\hline & & 60 & 0.969 & 0.208 & 0.043 & 0.943 & 0.175 & 0.031 \\
\hline \multirow{7}{*}{ Alder } & \multirow{3}{*}{0.01} & 25 & 0.913 & 0.120 & 0.014 & 0.814 & 0.389 & 0.151 \\
\hline & & 60 & 0.973 & 0.070 & 0.005 & 0.814 & 0.260 & 0.068 \\
\hline & & 80 & 0.976 & 0.136 & 0.018 & 0.929 & 0.202 & 0.041 \\
\hline & \multirow{2}{*}{0.15} & 25 & 0.909 & 0.222 & 0.033 & 0.641 & 0.435 & 0.149 \\
\hline & & 60 & 0.974 & 0.089 & 0.008 & 0.912 & 0.179 & 0.032 \\
\hline & \multirow{2}{*}{1.5} & 25 & 0.928 & 0.121 & 0.013 & 0.782 & 0.390 & 0.150 \\
\hline & & 60 & 0.969 & 0.138 & 0.019 & 0.943 & 0.175 & 0.031 \\
\hline
\end{tabular}

\section{Conclusions}

Drying of spruce, beech, willow, and alder sawdust in a laboratory dryer was examined. The impact of the temperature of drying air and the velocity of airflow was examined. Higher drying air temperatures and airflow velocity resulted in lower drying times and higher drying rates. The models, theoretical, semi-theoretical, and empirical thin-layer, were subject to investigation as regards their suitability to describe the drying of spruce, beech, willow, and alder sawdust. The correlation coefficient, root mean square error, and reduced chi-square were estimated for all the above mentioned models in order to compare the degree of their fitting to the experimental data on dehydration. All considered semi-theoretical and empirical models may be assumed to represent the drying of sawdust. The theoretical model of an infinite plane predicts the dehydration of sawdust better than the theoretical model of a sphere. It is possible to explain phenomena that occur during the process of drying using theoretical models. Semi-theoretical models or empirical models should be used to describe drying curves, if such description is needed. This is the requirement in practical drying. The impact of the drying variables on the parameters of the drying models for all considered models were determined. Statistical analysis was performed for the parameters of the models and for the drying conditions. The values of the ratio of the moisture diffusion coefficient to the square of the characteristic particle dimension $D / L^{2}$ increased with the increase in drying air temperature. The value of $D / L^{2}$ varied between $6.47 \times 10^{-5}$ and $4.58 \times 10^{-3} 1 / \mathrm{s}$.

The research focused on the method that allows the modelling of sawdust drying using parameters of models, which are not from experiments but from developed equations. Thanks to our research, it is possible to predict the course of the sawdust drying process with the given parameters of convection drying, namely temperature and air drying 
velocity. It is possible, therefore, to develop functions for other materials and other drying methods and to successfully use them for modelling of drying. Mathematical models of drying describe the kinetics of drying, which makes it possible to determine the drying time-a necessary parameter to determine the energy consumption for the drying process.

Author Contributions: Conceptualization, A.B., A.K., and K.G.; methodology, A.K. and K.G.; formal analysis, A.B. and A.K.; investigation, A.B., S.G., and P.W.; resources, A.B., W.T., and J.B.; writingoriginal draft preparation, A.K.; writing-review and editing, A.B., K.G., and W.T.; visualization, P.W.; supervision, S.G. All authors have read and agreed to the published version of the manuscript.

Funding: This research received no external funding.

Institutional Review Board Statement: Not applicable.

Informed Consent Statement: Not applicable.

Data Availability Statement: Not applicable.

Conflicts of Interest: The authors declare no conflict of interest.

\section{References}

1. Demirbaş, A. Biomass resource facilities and biomass conversion processing for fuels and chemicals. Energy Convers. Manag. 2001, 42, 1357-1378. [CrossRef]

2. Demirbas, A. Waste management, waste resource facilities and waste conversion process. Energy Convers. Manag. 2011, 52, 1280-1287. [CrossRef]

3. Zhang, L.; $\mathrm{Xu}, \mathrm{C}$.; Champagne, P. Overview of recent advances in thermo-chemical conversion of biomass. Energy Convers. Manag. 2010, 51, 969-982. [CrossRef]

4. Głowacki, S.; Tulej, W.; Sojak, M.; Bryś, A.; Jaros, M.; Szulc, D. Ultrasonic impact on the drying process of wood biomass. In Renewable Energy Sources: Engineering, Technology, Innovation; Springer: Cham, Switzerland, 2020; pp. 89-98. [CrossRef]

5. Chih, Y.K.; Chen, W.H.; Ong, H.C.; Show, P.L. Product Characteristics of Torrefied Wood Sawdust in Normal and Vacuum Environments. Energies 2019, 12, 3844. [CrossRef]

6. Gigler, J.K.; van Loon, W.K.P.; Sonneveld, C. Experiment and modelling of parameters influencing natural wind drying of willow chunks. Biomass Bioenergy 2004, 26, 507-514. [CrossRef]

7. Rupar, K.; Santini, M. The release of organic compounds during biomass drying depends upon the feedstock and/or altering drying heating medium. Biomass Bioenergy 2003, 25, 615-622. [CrossRef]

8. Hektor, B. Cost effectiveness of measures for the reduction of net accumulation of carbon dioxide in the atmosphere. Biomass Bioenergy 1998, 15, 299-309. [CrossRef]

9. Rösch, C.; Kaltschmitt, M. Energy from biomass-do non-technical barriers prevent an increased use? Biomass Bioenergy 1999, 16, 347-356. [CrossRef]

10. Głowacki, S.; Tulej, W.; Jaros, M.; Sojak, M.; Bryś, A.; Kędziora, R. Kinetics of drying silver birch (Betula pendula Roth) as an alternative source of energy. In Renewable Energy Sources: Engineering, Technology, Innovation; Springer: Cham, Switzerland, 2018; pp. 433-442.

11. Bilandžija, N.; Krička, T.; Matin, A.; Leto, J.; Grubor, M. Effect of harvest season on the fuel properties of sida hermaphrodita (L.) rusby biomass as solid biofuel. Energies 2018, 11, 3398. [CrossRef]

12. Križan, P.; Matú, M.; Šooš, L.; Beniak, J. Behavior of beech sawdust during densification into a solid biofuel. Energies 2015, 8, 6382-6398. [CrossRef]

13. Arce, M.E.; Saavedra, A.; Míguez, J.L.; Granada, E.; Cacabelos, A. Biomass fuel and combustion conditions selection in a fixed bed combustor. Energies 2013, 6, 5973-5989. [CrossRef]

14. Holmberg, H.; Ahtila, P. Comparison of drying costs in biofuel drying between multi-stage and single-stage drying. Biomass Bioenergy 2004, 26, 515-530. [CrossRef]

15. Rensröm, R. The potential of improvements in the energy systems of sawmills when coupled dryers are used for drying of wood fuels and wood products. Biomass Bioenergy 2006, 30, 452-460. [CrossRef]

16. Reddy, B.S. Biomass energy for India: An overview. Energy. Convers. Manag. 1994, 35, 341-361. [CrossRef]

17. Ståhl, M.; Granstrőm, K.; Berghel, J.; Renstrőm, R. Industrial process for biomass drying and their effects on the quality properties of wood pellets. Biomass Bioenergy 2004, 27, 621-628. [CrossRef]

18. Sheikholeslami, R.; Watkinson, A.P. Drying of wood residues in a fixed bed. In Convective Heat and Mass Transfer in Porous Media; Kluwer Academic Publishers: Dordrecht, The Netherlands, 1991; pp. 673-693.

19. Moreno, R.; Rios, R. Study on sawdust drying techniques in fluidized bed. Biosyst. Eng. 2002, 82, 321-329. [CrossRef]

20. Di Blasi, C.; Branca, C.C.; Speranoi, S.; La Manita, B. Drying characteristics of wood cylinders for conditions pertinent to fixed-bed countercurrent gasification. Biomass Bioenergy 2003, 25, 45-58. [CrossRef] 
21. Hansson, L.; Antti, A.L. The effect of microwave drying on Norway spruce wood strength: A comparison with conventional drying. J. Mater. Process. Technol. 2003, 141, 41-50. [CrossRef]

22. Hansson, L.; Antti, A.L. The effect of drying method and temperature level on the hardness of wood. J. Mater. Process. Technol. 2006, 171, 467-470. [CrossRef]

23. Karlsson, E.; Truedsson, I.; Stenström, S. Construction of a Flexible Pilot Dryer for Products Such as Biofuels and Iron Ore Pellets; Värmerforsk: Stockholm, Sweden, 2007; Report No. 1087.

24. Kobayashi, J.; Itaya, Y.; Tsukada, S.; Mizuno, K.; Ueda, M.; Morikawa, H.; Sugimoto, T.; Ueda, Y.; Oshika, Y.; Kobayashi, N.; et al. Drying technology of woody biomass for fine grinding by vibration mills. Asia Pac. J. Chem. Eng. 2007, 2, 83-89. [CrossRef]

25. Bengtsson, P. Experimental analysis of low-temperature bed drying of wooden biomass particles. Dry Technol. 2008, 26, 602-610. [CrossRef]

26. Kowalski, S.J.; Pawłowski, A. Drying of wood with air of variable parameters. Chem. Process. Eng. 2010, 31, 135-147. [CrossRef]

27. Lerman, P.; Wennberg, O. Experimental method for designing a biomass bed dryer. Biomass Bioenergy 2011, 35, S31-S35. [CrossRef]

28. Fagernäs, L.; Brammer, J.; Wilén, C.; Lauer, M.; Verhoeff, F. Drying of biomass for second generation synfuel production. Biomass Bioenergy 2010, 34, 1267-1277. [CrossRef]

29. Motevali, A.; Minaei, S.; Banakar, A.; Ghobadian, B.; Khoshtaghaza, M.H. Comparison of energy parameters in various dryers. Energy Convers. Manag. 2014, 87, 711-725. [CrossRef]

30. Şevik, S. Desing, experimental investigation and analysis of a solar drying system. Energy Convers. Manag. 2013, 68, 227-234. [CrossRef]

31. Falade, K.O.; Solademi, O.J. Modelling of air drying of fresh and blanched sweet potato slices. Int. J. Food Sci. Tech. 2010, 45, 278-288. [CrossRef]

32. Afriyie, J.K.; Rajakaruna, H.; Nazha, M.A.A.; Forson, F.K. Mathematical modelling and validation of the drying process in a Chimney-Dependent Solar Crop Dryer. Energy Convers. Manag. 2013, 67, 103-116. [CrossRef]

33. Colak, N.; Hepbasli, A. A review of heat pump drying: Part 1-Systems, models and studies. Energy Convers. Manag. 2009, 50, 2180-2186. [CrossRef]

34. Sopade, P.A.; Xun, P.Y.; Halley, P.J.; Hardin, M. Equivalence of the Peleg, Pilosof and SinghKulshrestha models for water absorption in food. J. Food Eng. 2007, 78, 730-734. [CrossRef]

35. Kaleta, A.; Górnicki, K. Some remarks on evaluation of drying models of red beet particles. Energy Convers. Manag. 2010, 51, 2967-2978. [CrossRef]

36. Reuss, M.; Benkert, S.; Aeberhard, A.; Martina, P.; Raush, G.; Rentzell, B.V.; Sogari, N. Modelling and experimental investigation of a pilot plant for solar wood drying. Sol. Energy 1997, 59, 259-270. [CrossRef]

37. TRNSYS; University of Wisconsin-Madison, Solar Energy Laboratory: Madison, VI, USA, 1994.

38. Fyhr, C.; Rasmuson, A. Some aspects of the modelling of wood chips drying in superheated steam. Int. J. Heat Mass. Tran. 1997, 40, 2825-2842. [CrossRef]

39. Johansson, A.; Fyhr, C.; Rasmuson, A. High temperature convective drying of wood chips with air and superheated steam. Int. J. Heat Mass Transf. 1997, 40, 2843-2858. [CrossRef]

40. Gigler, J.K.; van Loon, W.K.P.; van den Berg, J.V.; Sonneveld, C.; Meerdink, G. Natural wind drying of willow stems. Biomass Bioenergy 2000, 19, 153-163. [CrossRef]

41. Gigler, J.K.; van Loon, W.K.P.; Vissers, M.M.; Bot, G.P.A. Forced convective drying of willow chips. Biomass Bioenergy 2000, 19, 259-270. [CrossRef]

42. Dincer, I. Moisture transfer analysis during drying of slab woods. Heat Mass Transf. 1998, 34, 317-320. [CrossRef]

43. Weres, J.; Olek, W.; Guzenda, R. Identification of mathematical model coefficients in the analysis of the heat and mass transport in wood. Dry. Technol. 2000, 18, 1697-1708. [CrossRef]

44. Awadalla, H.S.F.; El-Dib, A.F.; Mohamad, M.A.; Reuss, M.; Hussein, H.M.S. Mathematical modelling and experimental verification of wood drying process. Energy Convers. Manag. 2004, 45, 197-207. [CrossRef]

45. Shruti, V.; Das, S.; Ting, Y.-P. Predictive modeling and response analysis of spent catalyst bioleaching using artificial neural network. Bioresour. Technol. Rep. 2020, 9, 100389. [CrossRef]

46. Omari, A.; Behroozi-Khazaei, N.; Sharifian, F. Drying kinetic and artificial neural network modeling of mushroom drying process in microwave-hot air dryer. J. Food Process Eng. 2018, 41, e12849. [CrossRef]

47. Özdemir, M.B.; Aktaş, M.; Şevik, S.; Khanlari, A. Modeling of a convective-infrared kiwifruit drying process. Int. J. Hydrog. Energy 2017, 42, 18005-18013. [CrossRef]

48. Balbay, A.; Şahin, Ö.; Karabatak, M. An investigation of drying process of shelled pistachios in a newly designed fixed bed dryer system by using Artificial Neural Network. Dry. Technol. 2011, 29, 1685-1696. [CrossRef]

49. Nadi, F.; Górnicki, K.; Winiczenko, R. A novel optimization algorithm for Echium amoenum petals drying. Appl. Sci. 2020, 10, 8387. [CrossRef]

50. Kaveh, M.; Chayjan, R.A. Mathematical and neural network modelling of terebinth fruit under fluidized bed drying. Res. Agric. Eng. 2016, 61, 55-65. [CrossRef]

51. Yüzgeç, U.; Türker, M. Comparison of different modeling concepts for drying process of baker's yeast. IFAC Proc. Vol. 2009, 42, 816-821. [CrossRef] 
52. Alara, O.R.; Abdurahman, N.H.; Olalere, O.A. Mathematical modelling and morphological properties of thin layer oven drying of Vernonia amygdalina leaves. J. Saudi Soc. Agric. Sci. 2017, 18, 309-315. [CrossRef]

53. Kaleta, A.; Górnicki, K.; Winiczenko, R.; Chojnacka, A. Evaluation of drying models of apple (var. Ligol) dried in a fluidized bed dryer. Energy Convers. Manag. 2013, 67, 179-185. [CrossRef]

54. Mghazli, S.; Ouhammou, M.; Hidar, N.; Lahnine, L.; Idlimam, A.; Mahrouz, M. Drying characteristics and kinetics solar drying of Moroccan rosemary leaves. Renew. Energy 2017, 108, 303-310. [CrossRef]

55. Hosseinabadi, H.Z.; Doosthoseini, K.; Layeghi, M. Drying kinetics of poplar (Populus Deltoides) wood particles by a convective thin layer dryer. Drv. Ind. 2012, 63, 169-176. [CrossRef]

56. Kaleta, A.; Górnicki, K. Evaluation of drying models of apple (var. McIntosh) dried in a convective dryer. Int. J. Food Sci. Technol. 2010, 45, 891-898. [CrossRef]

57. Lutovska, M.; Mitrevski, V.; Pavkov, I.; Babic, M.; Mijakovski, V.; Geramitcioski, T.; Stamenkovic, Z. Different methods of equilibrium moisture content determination. J. Process. Energy Agric. 2017, 21, 91-96. [CrossRef]

58. Srivastava, V.K.; John, J. Deep bed grain drying modeling. Energy Convers. Manag. 2002, 43, 1689-1708. [CrossRef]

59. Courtois, F. Dynamic Modelling of Drying to Improve Processing Quality of Corn. Ph.D. Thesis, ENSIA, Massy, France, 1997.

60. Lopez, A.; Pique, M.T.; Romero, A. Simulation on deep bed drying of hazelnuts. Dry. Technol. 1998, 16, 651-665. [CrossRef]

61. Pabis, S.; Jayas, D.S.; Cenkowski, S. Grain drying. Theory and Practice; John Wiley \& Sons: New York, NY, USA, 1998.

62. Sitompul, J.P.; Istadi; Widiasa, I.N. Modeling and simulation of deep-bed grain dryers. Dry. Technol. 2001, 19, 269-280. [CrossRef]

63. Ertekin, C.; Firat, M.Z. A Comprehensive review of thin layer drying models used in agricultural products. Crit. Rev. Food Sci. Nutr. 2015, 57, 701-717. [CrossRef]

64. Lewis, W.K. The rate of drying of solid materials. J. Ind. Eng. Chem. 1921, 13, 427-432. [CrossRef]

65. Henderson, S.M.; Pabis, S. Grain drying theory. I. Temperature effect on drying coefficient. J. Agric. Eng. Res. 1961, 6, 169-174.

66. Yagcioglu, A.; Degirmencioglu, A.; Cagatay, F. Drying characteristics of laurel leaves under different drying conditions. In Proceedings of the 7th International Congress on Agricultural Mechanization and Energy, Adana, Turkey, 26-27 May 1999; pp. 565-569.

67. Henderson, S.M. Progress in developing the thin-layer drying equation. Trans. ASAE 1974, 17, 72. [CrossRef]

68. Noomhorm, A.; Verma, L.R. A Generalized Single-Layer Rice Drying Model; ASAE Paper No: 86-3057; ASAE: St. Joseph, MI, USA, 1986.

69. Karathanos, V.T. Determination of water content of dried fruits by drying kinetics. J. Food Eng. 1999, 39, 337-344. [CrossRef]

70. Sharaf-Eldeen, Y.I.; Blaisdell, J.L.; Hamdy, M.Y. A model for ear corn drying. Trans. ASAE 1980, 23, 71. [CrossRef]

71. Verma, L.R.; Bucklin, R.A.; Endan, J.B.; Wratten, F.T. Effect of drying air parameters on rice drying models. Trans. ASAE 1985, 28, 296-301. [CrossRef]

72. Page, G.E. Factors Influencing the Maximum Rates of Air Drying Shelled Corn in Thin Layers. Master's Thesis, Purdue University, West Lafayette, IN, USA, 1949.

73. Hii, C.L.; Law, C.L.; Cloke, M. Modelling of thin layer drying kinetics of cocoa beans during artificial and natural drying. J. Food Sci. Tech. 2008, 3, 1-10.

74. Overhults, D.G.; White, H.E.; Hamilton, H.E.; Ross, I.J. Drying soybean with heated air. Trans. ASAE 1973, 16, 112-113. [CrossRef]

75. Ademiluyi, T.; Oboho, E.O.; Owudogu, M. Investigation into the thin layer drying models of Nigerian popcorn varieties. Leonardo Electr. J. Pract. Technol. 2008, 13, 47-62.

76. Demir, V.; Gunhan, T.; Yagcioglu, A.K. Mathematical modelling of convection drying of green table olives. Biosyst. Eng. 2007, 98, 47-53. [CrossRef]

77. Wang, C.Y.; Singh, R.P. A Single Layer Drying Equation for Rough Rice; ASAE Paper No: 78-3001; ASAE: St. Joseph, MI, USA, 1978.

78. Midilli, A.; Kucuk, H.; Yapar, Z. A new model for single-layer drying. Dry. Technol. 2002, 20, 1503-1513. [CrossRef]

79. STATISTICA (Data Analysis Software System); (StatSoft2011); version 10, StatSoft Polska Sp. z o.o., Krakow, Poland. Available online: www.statsoft.pl (accessed on 30 January 2021).

80. Gómez-de la Cruz, F.J.; Casanova-Pelaez, P.J.; López-Garcia, R.; Cruz-Peragón, F. Review of the drying kinetics of olive oil mill wastes: Biomass recovery. BioResources 2015, 10, 6055-6080. [CrossRef]

81. Doymaz, I. Evaluation of some thin-layer drying models of persimmon slices (Diospyros kaki L.). Energy Convers. Manag. 2012, 56, 199-205. [CrossRef]

82. Cunningham, S.E.; McMinn, W.A.M.; Magee, T.R.A.; Richardson, P.S. Modelling water absorption of pasta during soaking. J. Food Eng. 2007, 82, 600-607. [CrossRef]

83. Kaymak-Ertekin, F. Drying and rehydrating of green and red peppers. J. Food Sci. 2002, 67, 168-175. [CrossRef]

84. Bauer, K. Development and Optimisation of a Low-Temperature Drying Schedule for Eucalyptus Grandis (Hill) ex Maiden in a Solar-Assisted Timber Dryer. Ph.D. Thesis, Hohenheim University, Stuttgart, Germany, 2003.

85. Kashaninejad, M.; Motrazavi, A.; Safekordi, A.; Tabil, L.G. Thin-layer drying characteristics and modeling of pistachio nuts. J. Food Eng. 2007, 78, 98-108. [CrossRef]

86. Shi, Q.; Zheng, Y.; Zhao, Y. Mathematical modeling on thin-layer heat pump drying of yacon (Smallanthus sonchifolius) slices. Energy Convers. Manag. 2013, 71, 208-216. [CrossRef]

87. Cheevitsopon, E.; Noomhorm, A. Effect of paraboiling and fluidized bed drying on the physicochemical properties of germinated brow rice. Int. J. Food Sci. Tech. 2011, 46, 2498-2504. [CrossRef] 
88. Akpimar, E.; Midilli, A.; Bicer, Y. Single layer drying behaviour of potato slices on a convective cyclone dryer and mathematical modelling. Energy Convers. Manag. 2003, 44, 1689-1705. [CrossRef]

89. Pangavhane, D.R.; Sawhney, R.L.; Sarsavadia, P.N. Drying kinetics studies on single layer Thompson seedless grapes under controlled heated air conditions. J. Food Process. Pres. 2000, 24, 335-352. [CrossRef]

90. Toğrul, I.T.; Pehlivan, D. Modelling of drying kinetics of single apricot. J. Food Eng. 2003, 58, 23-32. [CrossRef]

91. Garcia-Pascual, P.; Sanjuán, N.; Bon, J.; Carreres, J.E.; Mulet, A. Rehydration process of Boletus edulis mushroom: Characteristic and modeling. J. Sci. Food Agric. 2005, 85, 1397-1404. [CrossRef]

92. Garcia-Pascual, P.; Sanjuán, N.; Melis, R.; Mulet, A. Marchella esculenta (morel) rehydration process modelling. J. Food Eng. 2006, 72, 346-353. [CrossRef]

93. Zielińska, M.; Markowski, M. Drying behaviour of carrots dried in spout-fluidized bed dryer. Dry. Technol. 2007, 25, 261-270. [CrossRef] 